\title{
Sosyal Bilgiler Öğretmenliği Öğrencilerinin Sosyal Medya Algılarının Metafor Yoluyla Belirlenmesi ${ }^{1}$
}

Şule Egü̈ ${ }^{2}$

\author{
Alper Kesten ${ }^{3}$
}

Type/Tür:

Research Article/Araştırma Makalesi

Received/Geliş Tarihi: March 3/3 Mart 2018

Accepted/Kabul Tarihi:

September 25/ 25 Eylül 2018

Page numbers/Sayfa No: 219-

240

Corresponding

Author/Illetişimden Sorumlu

Yazar: suleeguz@gmail.com

\section{$\checkmark$ iThenticate $^{\circ}$}

This paper was checked for plagiarism using iThenticate during the preview process and before publication. / Bu çalışma ön inceleme sürecinde ve yayımlanmadan önce iThenticate yazılımı ile taranmıştır.

Copyright (c) 2018 by Cumhuriyet University, Faculty of Education. All rights reserved.

\section{Öz}

Sosyal medya, eğitimden eğlenceye, ekonomiden sağlığa, çok çeşitli konularda birbirinden farklı kullanıcıları bir araya getirerek onların bilgi ve fikir paylaşımlarında bulunmalarını sağlayan bir ortamdır. Son yıllarda da bilgi ve iletişim teknolojileri alanında yaşanan gelişmelere paralel olarak da sosyal medyanın kullanımı her geçen gün artmaktadır. $\mathrm{Bu}$ çalışmanın amacı; Ondokuz Mayıs Üniversitesi Sosyal Bilgiler öğretmenliği öğrencilerinin sosyal medya algılarını metafor yoluyla belirlemektir. Nitel araştırmada metafor yöntemi kullanılarak hazırlanan bu çalışmada katılımcı öğrencilere, "sosyal medya............gibidir; çünkü.........." yazılı olan yarı yapılandırılmış formlar verilmiş ve buradan elde edilen ham veriler araştırmanın temel veri kaynağını oluşturmuştur. Veriler nitel veri çözümleme tekniklerinden içerik analizi yöntemiyle çözümlenmiştir. Elde edilen bulgular doğrultusunda araştırmaya katılan 132 öğrencinin yazdığı cümlelerden toplam 58 geçerli metafor üretilmiştir. Bu metaforlar daha sonra ortak özellikleri bakımından incelenerek 6 farklı kavramsal kategori altında toplanmıştır. Bu kategorilerden "yol gösteren ve bilgiye ulaştıran bir kaynak olarak sosyal medya", "bağımlılık yaratan bir unsur olarak sosyal medya" ve "gerçeği yansıtan ve etkileşimi sağlayan bir araç olarak sosyal medya" kategorileri tüm kategorilerin toplam \%78'ini temsil etmiştir. Ayrıca çalışmadaki 6 kavramsal kategori katılımcıların sınıf düzeyleri bakımından benzerlik göstermekle birlikte, sosyal medya algılarının genel olarak olumsuz olduğu belirlenmiştir.

Anahtar Kelimeler: Sosyal bilgiler öğretmenliği, öğrenci, sosyal medya, alg1, metafor

\section{Suggested APA Citation/Önerilen APA Atıf Biçimi:}

Egüz, Ş. ve Kesten, A. (2018). Sosyal bilgiler öğretmenliği öğrencilerinin sosyal medya algılarının metafor yoluyla belirlenmesi. Cumhuriyet International Journal of Education, 7(3), 219-240. http://dx.doi.org/10.30703/cije.403147

\footnotetext{
${ }^{1}$ Bu çalışmanın kısa bir özeti 23-25 Nisan 2015'te Bolu'da düzenlenen IV. Uluslararası Sosyal Bilgiler Eğitimi sempozyumunda sunulmuştur.

2 Dr. Öğr. Üyesi, İnönü Üniversitesi, Eğitim Fakültesi, Türkçe ve Sosyal Bilgiler Eğitimi Bölümü, Malatya/Türkiye

Dr, İnonu University, Faculty of Education, Department of Turkish and Social Studies Education,

Malatya/Turkey

e-mail:suleeguz@gmail.com

ORCID ID: https:/ / orcid.org/0000-0002-3633-8957

3Doç. Dr., Ondokuz Mayıs Üniversitesi, Eğitim Fakültesi, Türkçe ve Sosyal Bilgiler Eğitimi Bölümü, Samsun/Türkiye

Assoc. Prof., Ondokuz Mayıs University, Faculty of Education, Department of Turkish and Social Studies

Education, Samsun/Turkey

e-mail: alperkesten@gmail.com

ORCID ID: https:/ / orcid.org/0000-0003-2657-3168
} 


\title{
Identification of Perceptions of Social Media in Student-Teachers of Social Studies Through Metaphors
}

\begin{abstract}
Social networks bring together different users interested in quite various issues - from education to entertainment, economics to health - creating an environment where they can exchange information and ideas. In recent years, social media use has been o the increase in line with the advances in information and communication technologies. The present study aims to detect the social networks perceptions of social studies studentteachers at Ondokuz Mayıs University through metaphors. Qualitative research methods were used in the study where participating students were asked to complete statements such as 'Social networks are like ............. because .............', and this raw data constituted the basic source of research data. The data was processed for content analysis, one of the most commonly used techniques in qualitative data analysis. The findings suggest that a total of 58 valid metaphors were developed by 132 students who took part in the study. These metaphors can be grouped in six different conceptual categories in the light of their common features. Of these categories, 'Social networks as guiding sources of information', 'social networks as elements of addiction', and 'social networks as instruments for reflecting the truth and ensuring interaction' represented $78 \%$ of all the categories mentioned above. Further, despite the similarities in the six conceptual categories reflecting the participants' years of studies, their overall perceptions of social networks are in general rather negative.
\end{abstract}

Keywords: Social Studies teacher, student, social networks, perception, metaphors

\section{Giriș}

Tarih boyunca iletişimde kullanılan yöntemler ve telgraf, telefon, teleks, kamera, film, radyo ve televizyon gibi birçok iletişim aracı insanlığın değişip gelişmesinde önemli rol oynamıştır (Boyd-Barrett ve Braham, 2013). Günden güne değişen ve gelişen iletişim teknolojileri, bir yandan bireylerin toplumla bütünleşmesine, toplumun kültürel değerlerini benimsemelerine ve topluma yeni değerler eklenmesine katkıda bulunmakta diğer yandan toplumda meydana gelen inanç, tutum ve davranış değişikliklerinde önemli derecede rol oynamaktadır (Güz, 1996). $\mathrm{Bu}$ bağlamda bireyler medyanın yardımıyla aktif birer yorumcu haline gelerek eleştirici ve yaratıcı bir kimliğe bürünebilmektedirler (Das, 2010). Medya, kitle iletişim sürecinin en önemli organizasyon biçimi olarak toplumdaki olay ve oluşumları topluma yansıtarak; rasyonel davranabilen bireylerde genele yayılabilen menfaatlerin oluşmasına da yardımcı olmaktadır (Aydeniz, 2011; Kaya, 1999).

Günlük yaşantımızda önemli ölçüde yer edinmiş medyanın sosyal etkilerini anlamak ve kavramak için toplumun kültürel yapısı hakkında da bilgi sahibi olmak gerekmektedir (Koçoğlu, 2017; Rogge, 1989). Çünkü teknolojik, toplumsal ve kültürel değişimler temelde medyayı da değiştirmekte ve medyanın mevcut kültürün ulusal ve uluslararası düzeyde bireylere ulaştırılması noktasında önemli bir görev üstlenmesine neden olmaktadır (Jakubowicz, 2009; Kocadaş, 2006). Ancak medyanın kültürü geliştirmek - yaşatmak, bireylerin sağlıklı kişilik gelişimlerine katkıda bulunması gibi pozitif etkilerinin yanında ulusal kültürü yıpratan ve zayıflatan, bireylerin kişiliklerini ve ruh sağlıklarını olumsuz yönde etkileyen negatif etkileri de bulunmaktadır (Arslan, 2004). Bu bağlamda bazı uzmanlar, medya içeriğinin, Türk toplumunda şiddet, sapkınlık artışına, kişilik ve dürtü bozukluklarına sebep olduğunu tespit etmiş̧lerdir (Özdemir,1998; Palabıyıkoğlu, 1997). 
İletişim teknolojilerindeki hızlı gelişmeler internet, sosyal medya, sosyal ağlar gibi pek çok yeni kavramın medya literatürüne girmesini sağlamıştır. Bu yeni kavramlar arasında yer alan sosyal medya modern zamanların biçimlendirici araçlarından biri haline gelmiştir (Akçalı, 2009). Bugün anladığımız şekilde sosyal medya dönemi yaklaşık 20 yıl önce, Bruce ve Susan Abelson'un kurucuları olduğu "Açık Günlük" adı verilen bir topluluğun online günlük yazarlarını bir araya getiren sosyal ağ sitesini kurmasıyla başlamıştır (Kaplan ve Haenlein, 2010). Dünya üzerinde internet hızının artması ve geniş bant servislerinin çoğalmasıyla da kullanıcıların içerikleri düzenleyebildikleri, yayın ve yorum yapabildikleri birçok sosyal ağ sitesi kurulmuş ve geniş bir perspektif içinde de kendine yer bulmuştur (Kaplan ve Haenlein, 2010; Klieber, 2009). Bunlar (Hazar, 2011);

- Facebook, Instagram, MySpace, Linkedin, Friendster, Hi5, Friendfeed, Formspringa, Xing, Tagged gibi sosyal ağlar,

- Şirket blogları, Cnet, TheHuffington Post, BoingBoing, Techcrunch, Kottke, WordPress gibi bloglar,

- Youtube, Dailymotion, Google Videos, Yahoo Video, Vine, Periscope It's on gibi video paylaşım ağları,

- 1x, Flickr, Deviantart, Photosig, Fotocommunity, Photo, Photodom, Instagram, DeviantART, Pinterest, Snapchat gibi fotoğraf paylaşım ağları,

- Wikipedia, Intelipedia gibi Wiki tarzı bilgi paylaşım ağları,

- Twitter gibi mikroblogging paylaşım ağları gibi sitelerdir.

Türkiye'de ise 2004 yılında arkadaş bulabilmek amacıyla kurulan Yonja.com bu akımın ilk öncüsü olmuş ancak aynı yıl Facebook'un kurulmasıyla birlikte Türkiye'de sosyal medya kavramı yaygın bir şekilde kullanılmaya başlanmıştır (Gürbüz, 2014). Gündelik haber, bilgi veya iletişim amacının dışında, siyasi, ideolojik, ekonomik ve kültürel alanlarda da katılımı sağlayan sosyal medya (Barış, 2011; Blank ve Reisdorf, 2012); mobil ve web tabanlı teknolojiler aracılığıla interaktif platformlar oluşturarak ortak konular etrafında bireylerin tartışma ortamı yaratmasına firsat tanımaktadır (Büyükşener, 2009; Kietzmann, Hermkens, McCarthy ve Silvestre, 2011; Selwyn, 2012). Bu bakımdan sosyal medya kullanıcıları pasif bilgi tüketicileri olarak kabul edilmemelidir; onlar aynı zamanda interaktif ortamda işbirliği yapan bilgi üreticileridir (Dabbagh ve Kitsantas, 2012).

Sosyal medya günümüzde bireylere herhangi bir eğitim vaadinde bulunmamasına rağmen özellikle bilgiye ulaşmada ve toplumsal hayatta bireylerin çeşitli sosyal ihtiyaçlarını gidermede sık sık başvurulan bir kaynak durumundadır. Günümüzde kullanıcı sayısı milyonlara ulaşan sosyal medya sunduğu olanaklardan dolayı hem bireysel hem de sosyal hayatın ayrılmaz bir parçası haline gelmiş, insanların yaşam tercihlerini değişikliğe uğratmıştır (Barış ve Tosun, 2013; ŞişmanEren, 2014). Özellikle gençlerin arkadaş çevrelerini genişletmelerine imkân tanıması nedeniyle günümüzde popüler kültürün vazgeçilmez bir ögesi haline gelmiştir (Subrahmanyam, 2013). Yapılan çalışmalarda gençlerin \%22'sinin en sevdikleri sosyal medya ağında günde 10 defadan fazla oturum açtığı tespit edilmiştir (O'Keeffe ve Clarke-Pearson, 2011).

Gençler arasında inanılmaz bir hızla yaygınlaşan sosyal ağların bu gelişme süreciyle ve toplum üzerindeki olumlu olumsuz etkilerine yönelik alanyazına her 
gün bir başka çalışma girerken (Atıc1, 2010; Eroğlu ve Peker, 2011; Kaplan ve Haenlein, 2010; Şahin, Sarı, Özer ve Er, 2010), bu sosyal ağların en büyük kullanıcı kitlesini oluşturan gençlerin sosyal ağların kullanımı ve etkilerine ilişkin düşüncelerinin ne şekilde olduğunu gösteren çalışma sayısı ise oldukça az sayıdadır (Öztürk ve Akgün, 2012; Roblyer, McDaniel, Webb, Herman ve Witty, 2010; Tektaş, 2014). Kullanım yaşı neredeyse ilkokul çağına düşen sosyal ağların bilinçli kullanıminda kendilerinden büyük beklenti duyulan geleceğin Sosyal Bilgiler öğretmenleri olarak öğretmen adaylarının sosyal ağlar hakkındaki düşüncelerini inceleyen çalışma sayısı ise yok denecek kadar azdır. Bu amaçla, bu araştırma Ondokuz Mayıs Üniversitesi Sosyal Bilgiler öğretmenliği öğrencilerinin "sosyal medya" kavramını ne şekilde algıladıklarını ve nasıl tasvir ettiklerini anlayabilmek amacıyla dizayn edilmiştir. Bu doğrultuda öğrencilerden sosyal medyayı hem sözel hem de görsel metaforlarla anlatmaları istenmiş ve bu genel amaç çerçevesinde aşağıdaki sorulara yanıt aranmıştır:

- Gelecekte öğrencilerini bilinçli birer medya kullanıcısı olarak yetiştirmeleri beklenilen Sosyal Bilgiler öğretmen adayları zihinlerinde sosyal medyayı hangi metaforlarla ve nasıl canlandırmaktadır?

- Bu metaforlar doğrultusunda Sosyal Bilgiler öğretmen adaylarının "sosyal medya" hakkındaki görüşleri nelerdir?

- $\mathrm{Bu}$ kavramsal kategoriler Sosyal Bilgiler öğretmen adaylarının sınıf düzeyleri (1, 2, 3 ve 4. sinıflar) bakımından farklılık göstermekte midir?

\section{Yöntem}

Nitel araştırma yöntemine uygun olarak tasarlanan bu çalışmada veriler içerik analizi tekniğiyle çözümlenmiştir. İçerik analizi, kullanılan bağlamlara ve metinlere ilişkin geçerli ve anlamlı çıkarımlar yapabilmek için kullanılan bilimsel bir araştırma yöntemidir (Krippendorff, 2004).

\section{Çalışma Grubu}

Araştırmanın çalışma grubunu 2014-2015 eğitim öğretim yılı güz döneminde Ondokuz Mayıs Üniversitesi Eğitim Fakültesi Sosyal Bilgiler Öğretmenliğinde öğrenim gören 1, 2, 3 ve 4. sınıf öğrencileri oluşmaktadır (bkz. Tablo 1). Araştırmanın çalışma grubunun belirlenmesinde amaçlı örneklem seçimine gidilmiştir. $\mathrm{Bu}$ kapsamda, sosyal medyada en az bir üyeliği bulunan öğrenciler çalışmaya dahil edilmiştir. Amaçlı olarak seçilen örneklemde temel hedef, çalışılan konu ile ilgili olarak daha fazla bilgi sunacak bireyleri kullanmak ve sayı konusunda esnekliğe olanak sağlamaktır (Patton, 2002).

Araştırmaya $76^{\prime}$ s1 $(\% 57,60)$ k1z ve 56's1 da $(\% 42,40)$ erkek olmak üzere toplam 132 Sosyal Bilgiler öğretmeni katılmıştır. Öğrenciler sınıf düzeyine göre; $37(\% 28,00)$ birinci sınıf öğrencisi, $35(\% 26,60)$ ikinci sınıf öğrencisi, $24(\% 18,20)$ üçüncü sınıf öğrencisi ve $36(\% 27,20)$ dördüncü sınıf öğrencisi olarak dağılım göstermiştir. Araştırma etiği çerçevesinde katılımcıların isimleri çalışma içerisinde kullanılmamıştır. Bu nedenle katılımcı öğretmen adayları için 1. sınıf K1...K37, 2. sınıf M1...M35, 3. sınıf L1...L24, ve 4. sınıftaki katılımcılar için ise N1...N36 arasında değişen rumuzlar kullanılmıştır. 
Tablo 1

Katılımolar Hakkında Bilgi

\begin{tabular}{|c|c|c|c|c|c|c|c|}
\hline Katılımcılar & $\begin{array}{l}\text { Frekans } \\
\text { (f) }\end{array}$ & $\begin{array}{l}\text { Demografik } \\
\text { Özellik }\end{array}$ & $\begin{array}{l}\text { Frekans } \\
\text { (f) }\end{array}$ & $\begin{array}{l}\text { Yüzde } \\
(\%)\end{array}$ & Sinif & $\begin{array}{l}\text { Frekans } \\
\text { (f) }\end{array}$ & $\begin{array}{l}\text { Yüzde } \\
(\%)\end{array}$ \\
\hline \multirow[t]{4}{*}{ Öğrenciler } & \multirow[t]{4}{*}{132} & \multirow[t]{2}{*}{$\mathrm{K} 1 \mathrm{z}$} & \multirow[t]{2}{*}{76} & \multirow[t]{2}{*}{57,60} & 1.Sinif & 37 & 28,00 \\
\hline & & & & & 2.Sinif & 35 & 26,60 \\
\hline & & \multirow[t]{2}{*}{ Erkek } & \multirow[t]{2}{*}{56} & \multirow[t]{2}{*}{42,40} & 3.Sinif & 24 & 18,20 \\
\hline & & & & & 4.Sinif & 36 & 27,20 \\
\hline
\end{tabular}

\section{Verilerin Toplanması ve Analiz Edilmesi}

Araştırmada nitel araştırma veri toplama ve analiz yöntemleri kullanılmıştır. Katılımcıların 'sosyal medya' kavramına yönelik sahip oldukları metaforları ortaya koymak amacıyla her birinden, "sosyal medya..........gibidir; çünkü........." yazılı olan formlar verilerek tamamlamaları istenmiştir. Bu amaç için öğretmen adaylarına sayfanın en üstüne bu cümlenin yazılı olduğu formlar verilerek onlardan yalnızca bir metafor üzerinde yoğunlaşarak fikirlerini ifade etmeleri istenmiştir. Metaforların bir araştırma aracı biçiminde kullanıldı̆̆ı bu çalışmada "gibi" kavramı metaforun kaynağı ve konusu arasındaki ilişkiyi daha net bir biçimde ortaya koymak için kullanılmıştır. Ayrıca katılımcılardan sosyal medyanın günümüzdeki durumuna ilişkin bir benzetme üretmeleri ve mümkünse bunu görselleştirmeleri istenmiştir. Burada ise öğretmen adaylarının yazılı olarak ifade ettikleri sosyal medya algılarını görsel imgelere ne derece yansıttıklarını ortaya çıkarmak amaçlanmıştır. Formlardan elde edilen kompozisyonlar ve görseller araştırmanın temel veri kaynağını oluşturmuştur. Formların doldurulması sırasında ise öğretmen adaylarına yeterli süre tanınmıştır. Formlardan elde edilen nitel veri kaynakları içerik analizi yöntemiyle çözümlenmiştir. İçerik analizinde ise yapılan işlem, genel olarak birbirleriyle benzer özellik taşıyan verileri belli tema ve kavramlar bünyesinde bir araya getirmek ve bütün bunları okuyucunun anlayabileceği bir biçimde düzenleme yaparak yorumlamaktır (Yıldırım ve Şimşek, 2008). Bu çalışmada da öncelikle veriler kodlanarak frekans ve yüzde değerleri hesaplanmıştır. İçerik analizinin uygulanması, birtakım aşamalar halinde gerçekleşmektedir (Bilgin, 2014, s. 11). Bu araştırmada da geliştirilen metaforlar üç aşamada analiz edilmiştir;

1. Kodlama ve ayıklama aşaması: Katılımcıların formlarda belirttikleri metaforlar ve sebep cümleleri alfabetik olarak sıralanmıştır. Veri girişi sırasında metafor belirtilip, nedeni belirtilmeyen ya da tek formda birden fazla metafor belirten katılımcıların formları elenmiştir. Bu nedenlerle toplam 19 adet form değerlendirme dışı bırakılmıştır. Bir sonraki adımda metaforlar tekrar sıralanarak gözden geçirilmiştir. Burada katılımcıların 62 adet geçerli metafor ürettikleri tespit edilmiştir.

2. Örnek metafor imgesi derleme aşaması: Bu aşamada katılımcıların ürettikleri metaforlar, 'metaforun konusu', 'kaynağı', kaynak ve konu arasındaki ilişki bakımından incelenmiştir. Bu aşamada metafor kaynağı ve konusu arasında mantıklı ilişki kurulamadığı gerekçesiyle belirlenen 4 veri analizden çıkarılmıştır. Böylece 132 katılımcı tarafından 58 geçerli metafor olduğu tespit edilmiştir. 
3. Kategori geliştirme aşaması: Katılımcılar tarafından oluşturulan metaforlar 'kaynak ve konu arasındaki ilişki' göz önünde bulundurularak kategoriler geliştirilmiştir. Alanda bu konuyla ilgili yapılan başka bir çalışma olmadığından dolayı birbirine benzeyen metaforlar bir araya getirilerek araştırmacılar tarafından üst kategoriler oluşturulmuştur. Daha sonra ortaya çıkarılan kategoriler ve içerikleri eğitim alanında uzman iki araştırmacıya gönderilerek görüşleri alınmıştır. Bu görüşler doğrultusunda ortaya çıkan altı kategori ise yol gösteren ve bilgiye ulaştıran bir kaynak olarak sosyal medya bağımlılık yaratan bir unsur olarak sosyal medya, gerçeği yansıtan ve etkileşimi sağlayan bir araç olarak sosyal medya, zaman kaybı olarak sosyal medya, gereksinim olarak sosyal medya ve gizlenme alanı olarak sosyal medya olarak belirlenmiştir.

Ardından geliştirilen metaforlar kendi kategorilerinde değerlendirilmiştir. Araştırmanın doğruluk ve inandırıcılığını sağlamak için ise, araştırma katılımcılarının düşünceleri herhangi bir yoruma tabi tutulmaksızın olduğu gibi aktarılmıştır. Araştırma sonuçlarının inandırıcılığını sağlamak için kullanılan en önemli iki ölçüt geçerlik ve güvenirliktir. Elde edilen verilerin detaylı olarak raporlandırılması ve araştırmacının çalışma sonuçlara ne şekilde ulaştığını açıklaması nitel araştırmalarda geçerliğin önemli ölçütleri arasında bulunmaktadır (Yıldırım ve Şimşek, 2008). Bu araştırmada da 6 kavramsal metafor kategorisine nasıl ulaşıldığı detaylı olarak açıklanmıştır. Elde edilen 58 metaforun her biri için ise o metaforu en iyi temsil ettiği düşünülen bir katılımcı metafor imgesi belirlenerek bu imgelerin tamamına araştırmanın bulgular bölümünde yer verilmiş, bu şekilde araştırmanın geçerliği sağlanmıştır. Araştırmanın güvenirliğini sağlamak amacıyla araştırmada elde edinilen kavramsal kategori kapsamında verilen metaforların belirlenen kavramsal kategoriyi sembolize edip etmediğini doğrulamak amacıyla uzman görüşüne sunulmuştur. Bu doğrultuda aynı programda bulunan bir öğretim üyesine 58 adet örnek metafor imgesinin alfabetik sıralı listesi ile 6 kavramsal kategorinin özelliklerinin yer aldığı liste verilerek hiçbir metafor dışarıda bırakılmayacak şekilde eşleştirmesi istenmiştir. Daha sonra araştırmacılar yaptığı eşleştirmeler ile uzman tarafından yapılan eşleştirmeler karşılaştırılmıştır. Karşılaştırmalarda görüş birliği ve görüşs ayrılığı sayıları tespit edilerek Miles ve Huberman'ın (1994) formülü (Güvenirlik Formülü = Görüş birliği / Görüş birliği + Görüş ayrılığı) ile hesaplanmıştır. Miles ve Huberman (1994) güvenirlik sonucunun \%70'in üzerinde çıkmasının araştırmanın güvenirliği için geçerli bir oran olduğunu savunmuştur. Bu araştırmaya yönelik yapılan güvenirlik çalışmasında \%95 oranında bir güvenirlik sağlanmıştır (Güvenirlik=58/58+3=0,95).

\section{Bulgular}

Bu bölümde çalışmaya katılan 132 Sosyal Bilgiler Öğretmenliği 1, 2, 3 ve 4. sınıf öğrencisinin sosyal medya hakkındaki görüşleri 3 ana başlik altında sunulmuştur. Bunlar; Sosyal Bilgiler öğretmenliği öğrencilerinin "sosyal medya" kavramina yönelik oluşturdukları metaforlar", Sosyal Bilgiler öğrencilerinin geliştirdikleri metafor kategorileri, kategorilerin öğrencilerin sınıf düzeyi bakımından karşılaştırılmasıdır. 


\section{Sosyal Bilgiler Öğretmenliği Öğrencilerinin "Sosyal Medya" Kavramına Yönelik Oluşturdukları Metaforlar}

Sosyal Bilgiler Öğretmenliği Öğrencilerinin "Sosyal Medya" Kavramina Yönelik metaforik algılarıyla ilgili veriler analiz edildiğinde Tablo 2'de verilen sonuçlar ortaya çıkmıştır.

\section{Tablo 2}

Sosyal Bilgiler Öğretmenliği 1, 2, 3 ve 4. Sınıf Öğrencilerinin Sosyal Medya İçin Oluşturdukları Metaforlar

\begin{tabular}{|c|c|c|c|c|c|}
\hline Oluşturulan Metafor & $\begin{array}{l}\text { Frekans } \\
(f)\end{array}$ & $\begin{array}{l}\text { Yüzde } \\
(\%)\end{array}$ & Oluşturulan Metafor & $\begin{array}{l}\text { Frekans } \\
(f)\end{array}$ & $\begin{array}{l}\text { Yüzde } \\
(\%)\end{array}$ \\
\hline 1-Uyuşturucu & 17 & 12,70 & 30-Kum saati & 1 & 0,70 \\
\hline 2-Su & 8 & 6,80 & 31-Maskeli Balo & 1 & 0,70 \\
\hline 3-Dünya & 6 & 4,50 & 32-Moda akımı & 1 & 0,70 \\
\hline 4-Virüs & 6 & 4,50 & 33-Bedevi & 1 & 0,70 \\
\hline 5-Sigara & 5 & 3,70 & 34-Cadı Kazanı & 1 & 0,70 \\
\hline 6-Okyanus & 5 & 3,70 & 35-Yarış atı & 1 & 0,70 \\
\hline 7-Arkadaş & 5 & 3,70 & 36-Pazar yeri & 1 & 0,70 \\
\hline 8-Hirs1z & 4 & 3,70 & 37-Oyuncak & 1 & 0,70 \\
\hline 9-Canavar & 4 & 3,70 & 38-Kasaba & 1 & 0,70 \\
\hline 10-Çöp Kutusu & 4 & 3,70 & 39-Elma kurdu & 1 & 0,70 \\
\hline 11-Serum & 4 & 3,70 & 40-Kartal & 1 & 0,70 \\
\hline 12-Örümcek Ağ1 & 3 & 2,20 & 41-Çekirdek & 1 & 0,70 \\
\hline 13-Gazete & 3 & 2,20 & 42-Güneş & 1 & 0,70 \\
\hline 14-Hapishane & 3 & 2,20 & 43-Bebek & 1 & 0,70 \\
\hline 15-Aptal Kutusu (TV) & 3 & 2,20 & 44-Baharat & 1 & 0,70 \\
\hline 16- Düşman & 3 & 2,20 & 45-İlistir & 1 & 0,70 \\
\hline 17-İdareci & 3 & 2,20 & 46-Uzay boșluğu & 1 & 0,70 \\
\hline 18-Ayna & 2 & 1,50 & 47-Diktatör & 1 & 0,70 \\
\hline 19-Kartopu & 2 & 1,50 & 48-Gece gündüz & 1 & 0,70 \\
\hline 20-Batak & 2 & 1,50 & 49-Hayat & 1 & 0,70 \\
\hline 21-Çikolata & 2 & 1,50 & 50-Hücre & 1 & 0,70 \\
\hline 22- Ağaç & 2 & 1,50 & 51-Boş sayfa & 1 & 0,70 \\
\hline 23-Öğretmen & 1 & 0,70 & 52-Telgraf teli & 1 & 0,70 \\
\hline 24-Lastik & 1 & 0,70 & 53-Uyku & 1 & 0,70 \\
\hline 25-Zurna & 1 & 0,70 & 54-Ruhsuz Beden & 1 & 0,70 \\
\hline 26-İşçi & 1 & 0,70 & 55-Popüler bir şark1 & 1 & 0,70 \\
\hline 27-Organ & 1 & 0,70 & 56-Volkan & 1 & 0,70 \\
\hline 28-Yol & 1 & 0,70 & 57-Çay & 1 & 0,70 \\
\hline 29-Obezite & 1 & 0,70 & 58-Kitap kapağ1 & 1 & 0,70 \\
\hline
\end{tabular}

Tablo 2'de görüleceği üzere araştırmaya katılan öğrenciler tarafından "sosyal medya" kavramına yönelik toplam 58 metafor geliştirilmiştir. Katılımcıların \% 12.70 'sinin $(f=17)$ sosyal medyayı, "uyuşturucu"ya benzettiği görülmektedir. Buna gerekçe olarak da sosyal medyanın "bağımlılık yapan" bir özelliğinin olması açıklamasında bulunmuşlardır. Katılımcıların \%6.80'i $(f=8)$ ise geliştirdikleri metaforlar "su" kategorisinde birleşmiştir. Bu görüşte olan öğrenciler ise, sosyal medyayı "su" ya benzetme nedenleri olarak "temel ihtiyaç" olarak gördüklerini ifade etmişlerdir. Bunun dişında "dünya \%4.50 $(f=6)$, virüs \%4.50 $(f=6)$, sigara \%3.70 $(f=5)$, okyanus \%3.70 $(f=5)$, arkadaş \%3.70 $(f=5)$, hırsız \%3.70 $(f=4)$, canavar \%3.70 $(f=5)$, çöp 
kutusu \%3.70 $(f=5)$, serum \%3.70 $(f=5)^{\prime \prime}$ metaforları sıkça kullanılan metaforlar olmuştur.

\section{Sosyal Bilgiler Öğrencilerinin Geliştirdikleri Metafor Kategorileri}

Araştırmaya katılan Sosyal Bilgiler öğrencilerinin oluşturdukları metaforlar Tablo 3'te kendi aralarında 6 kategoride değerlendirilmiştir. Bu kategoriler; "yol gösteren ve bilgiye ulaştıran bir kaynak olarak sosyal medya", "bağımlılık yaratan bir unsur olarak sosyal medya", "gerçeği yansitan ve etkileşimi sağlayan bir araç olarak sosyal medya", "zaman kaybı olarak sosyal medya", "gereksinim olarak sosyal medya" ve "gizlenme alanı olarak sosyal medya" olarak belirlenmiştir. Tablo 3'te Sosyal Bilgiler Öğretmenliği öğrencilerinin geliştirdikleri metafor kategorileri ile bu kategorilerin dağılımı gösterilmektedir.

Tablo 3 incelendiğinde öğrencilerin geliştirdikleri metafor kategorilerinden 'yol gösteren ve bilgiye ulaştıran bir kaynak olarak sosyal medya' kategorisinde 50 öğrenci toplam 24 farklı metafor üretmiş ve bu kategori öğrencilerin en fazla metafor ürettiği kategori olmuştur $(\% 37,70)$. 'Bağımlılık yaratan bir unsur olarak sosyal medya' kategorisinde ise 38 öğrenci toplam 12 metafor üretirken $(\% 28,70)$; 'gerçeği yansitan ve etkileşimi sağlayan bir araç olarak sosyal medya' kategorisinde 15 öğrenci toplam 10 metafor $(\% 11,70)$ geliştirmiştir. 'Zaman kaybı olarak sosyal medya' kategorisinde 16 öğrenci 6 farklı metafor üretirken; 'gereksinim olarak sosyal medya' kategorisinde ise 12 öğrenci toplam 5 metafor $(\% 9,70)$ geliştirmiştir. Sosyal medyay1 gizlenme alanı olarak gören 1 öğrenci de bu kategoride tek bir metafor $(\% 0,70)$ üretmiştir.

Yol gösteren ve bilgiye ulaştıran bir kaynak olarak sosyal medya. Tablo 3'e göre "yol gösteren ve bilgiye ulaştıran bir kaynak olarak sosyal medya" kategorisiyle ilgili; dünya, virüs, okyanus, çöp kutusu, serum, gazete, ağaç, kartopu, idareci, yol, diktatör, öğretmen, kitap kapağı, kartal, pazar yeri, telgraf teli, volkan, cadı kazanı, işçi, bedevi, yarış atı, baharat, zurna, lastik metaforları geliştirilmiş ve en fazla metafor geliştirilen kategori olmuştur. Katılımcıların \%37.70'si ( $\mathrm{f}=50)$ bu kategoride toplam 24 farklı metafor geliştirmişlerdir. Katılımcılar tarafından oluşturulan bu kategoriyle ilgili bazı metafor örnekleri aşağıda verilmiştir.

"Sosyal medya dünya gibidir, çünkü uzakları yakın edip anında bilgiye ulaştırır."(K4)

"Sosyal medya yarış atı gibidir, çünkü yarış atları gideceği yolu bilir, eğitilmişlerdir. Sosyal medya kullanıcıları da istediklerine ulaşabilecek tüm yolları bilir." (K23)

"Sosyal medya okyanus gibidir, çünkü sınırları, konusu belli değildir. İçeriği iyi de kötü de olabilir. Bilgileri iyiye kullananlar için denilecek bir şey yok. Fakat kötüye kullanan için o okyanus ölüm tehlikesi yaratabilir." (M13)

"Sosyal medya virüs gibidir, çünkü her türlü bilgi, fikir vb. hızla ve çok geniş kitlelere yayılır." (L3)

"Sosyal medya telgraf telleri gibidir, çünkü kısa sürede dünyanın her yerine hızl haberleşme ve bilgi gönderme imkanı sağlamaktadır." (N17)

"Sosyal medya baharat gibidir, çünkü her çeşit bilgiyi içinde barındırır." (N22) 
Tablo 3

Sosyal Bilgiler Öğretmenliği 1, 2, 3 ve 4. Sinı Öğrencilerinin Geliştirdikleri Metafor Kategorileri

\begin{tabular}{|c|c|c|c|c|}
\hline Kategoriler & Metafor Adları & $\begin{array}{l}\text { Metafor } \\
\text { Sayisı }\end{array}$ & $\begin{array}{l}\text { Metafor } \\
\text { Frekansı } \\
\text { (öğrenci } \\
\text { sayıs1) }\end{array}$ & $\begin{array}{l}\text { Metafor } \\
\text { Yüzdesi } \\
(\%)\end{array}$ \\
\hline $\begin{array}{l}\text { Yol gösteren ve } \\
\text { bilgiye ulaştıran bir } \\
\text { kaynak olarak sosyal } \\
\text { medya }\end{array}$ & $\begin{array}{l}\text { Dünya (6), virüs (6), okyanus (5), } \\
\text { çöp kutusu (4), serum (4), gazete } \\
\text { (3), ağaç (2), kartopu (2), idareci (3), } \\
\text { yol (1), diktatör (1), ögrretmen (1), } \\
\text { kitap kapağı (1), kartal (1), pazar } \\
\text { yeri (1), telgraf teli (1), volkan (1), } \\
\text { cadı kazanı (1), işçi (1), bedevi (1), } \\
\text { yarış atı (1), baharat (1), zurna (1), } \\
\text { lastik (1) }\end{array}$ & 24 & 50 & 37,70 \\
\hline $\begin{array}{lr}\text { Bağımlılık yaratan } \\
\text { bir unsur } & \text { olarak } \\
\text { sosyal medya } & \end{array}$ & $\begin{array}{l}\text { Uyuşturucu (17), sigara (5), } \\
\text { örümcek ağı (3), hapishane (3), } \\
\text { çikolata (2), batak (2), çay (1), } \\
\text { çekirdek (1), elma kurdu (1), ruhsuz } \\
\text { beden (1), obezite (1), uzay boşluğu } \\
\text { (1) }\end{array}$ & 12 & 38 & 28,70 \\
\hline $\begin{array}{l}\text { Gerçeği yansitan ve } \\
\text { etkileşimi sağlayan } \\
\text { bir araç olarak sosyal } \\
\text { medya }\end{array}$ & $\begin{array}{l}\text { Arkadaş (5), ayna (2), hayat (1), } \\
\text { kasaba (1), ilistir (1), popüler bir } \\
\text { şarkı (1), moda akımı (1), gece ve } \\
\text { gündüz (1), bebek (1), boş sayfa (1) }\end{array}$ & 10 & 15 & 11,70 \\
\hline $\begin{array}{l}\text { Zaman kaybı olarak } \\
\text { sosyal medya }\end{array}$ & $\begin{array}{l}\text { Hırsiz (4), canavar (4), aptal kutusu } \\
\text { (TV) (3), düşman (3), kum saati (1), } \\
\text { oyuncak (1) }\end{array}$ & 6 & 16 & 12,10 \\
\hline $\begin{array}{l}\text { Gereksinim olarak } \\
\text { sosyal medya }\end{array}$ & $\begin{array}{l}\text { Su (8), organ (1), Uyku (1), güneş } \\
\text { (1), hücre (1) }\end{array}$ & 5 & 12 & 9,70 \\
\hline $\begin{array}{l}\text { Gizlenme alanı } \\
\text { olarak sosyal medya }\end{array}$ & Maskeli Balo (1) & 1 & 1 & 0,70 \\
\hline
\end{tabular}

Katılımcıların sosyal medya algılarıyla ilgili çizdikleri benzetmeler ve bunlarla ilgili görüşleri Tablo 4'te verilmiştir. 
Tablo 4

Öğrencilerin 'Sosyal Medya' Algularıla İgili Benzetmeleri

\begin{tabular}{|c|c|c|}
\hline & Resim & Görüş \\
\hline \multicolumn{3}{|l|}{1} \\
\hline & foceboon & $\begin{array}{l}\text { "Sosyal medya okyanus gibidir, çünkü sınırları, } \\
\text { konusu belli değildir. İçeriği iyi de kötü de } \\
\text { olabilir. Bilgileri iyiye kullananlar için denilecek } \\
\text { bir şey yok. Fakat kötüye kullanan için o } \\
\text { okyanus ölüm tehlikesi yaratabilir." (M13) }\end{array}$ \\
\hline 2 & & $\begin{array}{l}\text { "Sosyal medya virüs gibidir, çünkü her türlü } \\
\text { bilgi, fikir vb. hızla ve çok geniş kitlelere } \\
\text { yayılır." (L3) }\end{array}$ \\
\hline
\end{tabular}

Bağımlılık yaratan bir unsur olarak sosyal medya. "Bağımlılık yaratan bir unsur olarak sosyal medya" kategorisinde ise, uyuşturucu, sigara, örümcek ağı, hapishane, çikolata, batak, çay, çekirdek, elma kurdu, ruhsuz beden, obezite, uzay boşluğu metaforları katılımcılar tarafından geliştirilmiştir. $\mathrm{Bu}$ kategoride katılımcıların \%28,70'i (f=38) toplam 12 farklı metafor geliştirmişlerdir. Sosyal Bilgiler Öğretmenliği öğrencileri oluşturdukları metaforları aşağıda yer alan örneklerdeki gibi tanımlamışlardır.

"Sosyal medya sigara gibidir, çünkü hem insanı kendisine bağlar hem stresi alır hem de insana zarar verir." (K7)

"Sosyal medya uzay boşluğu gibidir, çünkü bir kere içine girince kaybolup gidersin, bir hiç olursun, bir daha da çıkamazsin." (K19)

"Sosyal medya bonzai (uyuşturucu) gibidir, çünkü insanlarn belli kalıplara sıkıştırarak insanlarm beyinlerini abluka altına alır, onlar sanal dünyaya hapseder ve neticede insanlar toplumsal hayattan soyutlar ve bu ileride de insanlar toplumdan soyutlandığ için daha doğrusu kendi kendini soyutladığı için güvensizlik, korku, silik olma düşüncelerine mahkum eder, kendine bağlar." (M7)

"Sosyal medya çay gibidir, çünkü bağımlılık yapar, sürekli istersin." (L17)

"Sosyal medya örümcek ăgı gibidir, çünkü uzaktan fark edemezsiniz fakat ăgın içine girdiğinizde sizi yakalar ve siz hareket ettikçe sizi sarmaya başlar. Bunu uzun zamana yaydı̆̆ınıda ise tüm işlerinizi sosyal ağlar ile yapıyor bulursunuz kendinizi." (N4)

"Sosyal medya elma kurdu gibidir, çünkü içimize girer girmez, aklımıza düşer düşmez bizi kendisine hapseder, sonunda bizi bitirir, işlerimizi yapamaz hale geliriz." (N3)

Katılımcların sosyal medya algılarıyla ilgili çizdikleri benzetmeler ve bunlarla ilgili görüşleri Tablo 5'te verilmiştir. 
Tablo 5

Öğrencilerin 'Sosyal Medya' Algılarıla İlgili Benzetmeleri

\begin{tabular}{l} 
Resim \\
\hline 1
\end{tabular}

Gerçeği yansıtan ve etkileşimi sağlayan bir araç olarak sosyal medya. Bu kategoride oluşturulan metaforlarda sosyal medya; gerçeği yansıtan ve etkileşimi sağlayan bir araç olarak ifade edilmiştir. Oluşturulan metaforlar ise arkadaş, ayna, hayat, kasaba, ilistir, popüler bir şarkı, moda akımı, gece ve gündüz, bebek, boş sayfa olarak belirlenmiştir. Bu kategoride katılımcıların \%11,70'si $(\mathrm{f}=15)$ toplam 10 farklı metafor geliştirmişlerdir. Katılımcılar tarafından oluşturulan bu kategoriyle ilgili yaptıkları tanımlamalardan bazılarına aşağıda yer verilmiştir.

"Sosyal medya kasaba gibidir, çünkü sosyal medya sayesinde mesafeler bir tuş ötede olmakla birlikte ülkelerin, kntalarm birbirleriyle etkileşimi de bu sayede giderek artmakta, kolaylaşmakta ve dünya giderek küçük bir kasaba görüntüsü almaktadır." (K2)

"Sosyal medya moda akımı gibidir, çünkü insanlar çoğunluk ne yaparsa onu yapmaya çalışıyorlar. İstemesen de kendini içinde bulursun. Sosyal medyada insanlar yedikleri, gezdikleri, giydiklerini sergiliyorlar. Bunları görenlerde aynısın yapıyor. Insanları aynı tipe sokuyor." (K26)

"Sosyal medya arkadaş gibidir, çünkü benim telefonum ve bilgisayarmm her şeyim. Hiç benden ayrılmıyorlar. Sabah uyandığımda ilk günaydınları onlardan alıyorum." (M3)

"Sosyal medya ayna gibidir, çünkü sosyal medyanın verdiği haberler insanlarm onu algıladıkları gibidir. Bu algılama insanın yeri geldi olumlu yeri geldi olumsuz özelliklerini vurgular." (L4)

"Sosyal medya bebek gibidir, çünkü bilinçli bir ebeveyn olursanız olaylar olumlu yani sizin istediğiniz veya olması gerektiği gibi gelişir. Eğer bilinçsiz bir ebeveyn olursanız başta tehlikesiz gibi görünen durumları önemsemezseniz daha sonra kontrol edemez ve faydasindan çok zararını görürsünüz." (N16)

"Sosyal medya popüler bir şarkı gibidir, çünkü başkasında gördüğümüzü, duyduğumuzu hemen sosyal medya üzerinde uyguları." (N35) 
Katılımcıların sosyal medya algılarıyla ilgili çizdikleri benzetmeler ve bunlarla ilgili görüşleri Tablo 6' te verilmiştir.

Tablo 6

Öğrencilerin 'Sosyal Medya' Algılarıla İlgili Benzetmeleri

\begin{tabular}{l} 
Gesim \\
\hline 1
\end{tabular} $\begin{aligned} & \text { "Sosyal medya kasaba gibidir, çünkü sosyal } \\
& \text { medya sayesinde mesafeler bir tuş ötede } \\
& \text { olmakla birlikte ülkelerin, kitaların birbirleriyle } \\
& \text { etkileşimi de bu sayede giderek artmakta, } \\
& \text { kolaylaşmakta ve dünya giderek küçük bir } \\
& \text { kasaba görüntüsü almaktadır." (K2) }\end{aligned}$

Zaman kaybı olarak sosyal medya. Bu kategoride hırsız, canavar, aptal kutusu (TV), düşman, kum saati, oyuncak metaforları zaman kaybı olarak sosyal medya kategorisinde bir araya gelmişlerdir. Katılımcıların \%12,10'i ( $f=16)$ bu kategoride toplam 6 farklı metafor geliştirmişlerdir. Katılımcıların bu kategorideki tanımlamaları aşağıdaki cümlelerle örneklendirilmiştir.

"Sosyal medya hırsız gibidir, çünkü hayatımıza pek bir şey katmamasına rağmen zamanımızın çoğunu bizden çalar ve bir daha o zamanımız geri getirmez." (K3)

"Sosyal medya aptal kutusu (TV) gibidir, çünkü insanlarn saatlerce sosyal medyada vakit geçirmelerinin onları aptallaştırdığını düşünüyorum." (K31)

"Sosyal medya canavar gibidir, çünkü insanlar can sıkıntılarını burada attıkları düşünüyor, ancak zamanlarını öldürüyor." (M6)

"Sosyal medya kum saati gibidir, çünkü zamanın nasıl geçtiğini anlayamayız."(L8)

"Sosyal medya oyuncak gibidir, çünkü insanlar oyalanmak, vakit harcamak ya da stres atmak için medyay takip ederler. Bir de bakmışlar tüm zamanları gitmiş." (L19)

"Sosyal medya düşman gibidir, çünkü insanlar arasındaki ilişkinin bozulması, iletişimin yok derece denilebilecek seviyeye inmesine neden olmaktadır." (N33)

Katılımcıların sosyal medya algılarıyla ilgili çizdikleri benzetmeler ve bunlarla ilgili görüşleri Tablo 7' de verilmiştir. 
Tablo 7

Öğrencilerin 'Sosyal Medya' Algılarıla İlgili Benzetmeleri

\begin{tabular}{l|l|l}
\hline \multicolumn{1}{c|}{ Resim } & \begin{tabular}{l} 
Görüş \\
\hline 1
\end{tabular} & $\begin{array}{l}\text { Sosyal medya hirsız gibidir, çünkü hayatımıza } \\
\text { pek bir şey katmamasına rağmen zamanımızın } \\
\text { çoğunu bizden çalar ve bir daha o zamanımız } \\
\text { geri getirmez." (K3) }\end{array}$ \\
\hline
\end{tabular}

Gereksinim olarak sosyal medya. Bu kategoride oluşturulan metaforlar, su, organ, uyku, güneş, hücre olarak belirlenmiştir. Katılımcıların \%9,70'si (f=12) bu kategoride toplam 5 farklı metafor geliştirmişlerdir. Katılımcılar tarafından oluşturulan bu kategoriyle ilgili bazı metafor örnekleri aşağıda verilmiştir.

"Sosyal medya hücre gibidir, çünkü canlıları oluşturan yapıdır."(K32)

"Organ gibidir, hatta beyin gibidir. Beyin olmadan kendimizi idare edemeyiz. Sosyal medyada olmadan hayat felç olur." (M28)

"Sosyal medya su gibidir, çünkü okulda veya iş hayatında sosyal medyaya her zaman ihtiyaç vardir." (M32)

"Sosyal medya uyku gibidir, çünkü insan uykusuz kaldiğında nasıl sersem, solgun, bitkin olursa sosyal medya olmadı̆̆ında da aynısı olur." (M35)

"Sosyal medya su, yemek gibidir, çünkü olmadığında insan bunalıma girer, mutlaka olmalıdır." (L20)

"Sosyal medya güneş gibidir, çünkü güneş canlılar için olmazsa olmazdır. Sosyal medya da insanlar için olmazsa olmaz bilgi edinme; bilgiye, habere ulaşmanın en önemli kaynağıdır." (N13)

Katılımcıların sosyal medya algılarıyla ilgili çizdikleri benzetmeler ve bunlarla ilgili görüşleri Tablo 8'te verilmiştir. 
Tablo 8

Öğrencilerin 'Sosyal Medya' Algzlarula İlgili Benzetmeleri

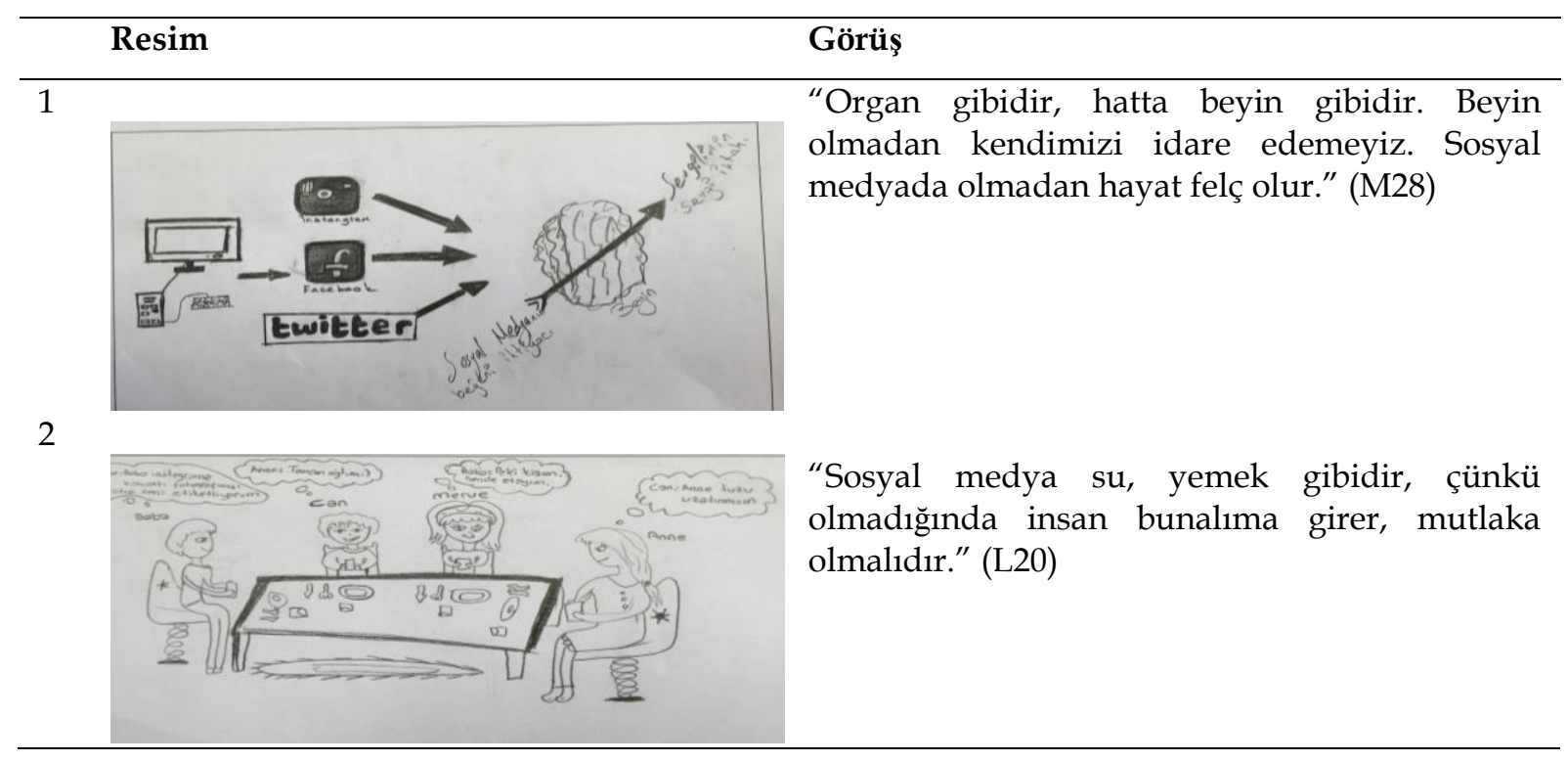

Gizlenme alanı olarak sosyal medya. Bu kategoride araştırmaya katılan 4. sınıf Sosyal Bilgiler öğretmenliği öğrencilerinden sadece biri tarafından tek bir metafor (maskeli balo) geliştirilmiştir. Katılımcı N29, gizlenme alanı olarak gördüğü sosyal medyayı şu sözleriyle ifade etmiştir;

"Sosyal medya maskeli balo gibidir, çünkü sosyal medyada insanlar gerçek hayatlarnndaki kimliklerinden çok farkl kimliklere bürünebilmekte ve günlük yaşantılarında dile getiremedikleri tüm fikirlerini hiçbir şeyden çekinmeden (ahlak kurallar dahi) söylemektedirler." (N29)

Katılımcların sosyal medya algılarıyla ilgili çizdikleri benzetmeler ve bunlarla ilgili görüşleri Tablo 9'da verilmiştir.

Tablo 9

Öğrencilerin 'Sosyal Medya' Algılarıla İlgili Benzetmeleri

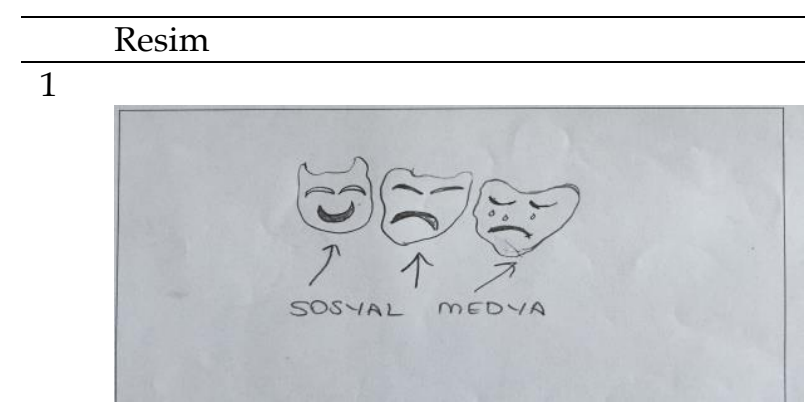
Görüş

“Sosyal medya maskeli balo gibidir, çünkü sosyal medyada insanlar gerçek hayatlarındaki kimliklerinden çok farklı kimliklere bürünebilmekte ve günlük yaşantılarında dile getiremedikleri tüm fikirlerini hiçbir şeyden çekinmeden (ahlak kuralları dahi) söylemektedirler." (N29) 


\section{Kategorilerin Öğrencilerin Sınıf Düzeyi Bakımından Karşılaştırılması}

Sosyal Bilgiler öğrencilerinin oluşturdukları metaforlara bağlı olarak geliştirilen 6 kavramsal kategorinin öğrencilerin sınıf düzeyi bakımından dağılımı Tablo 10'da gösterilmiştir.

Tablo 10

Altı Kavramsal Kategorinin Öğrencilerin Sınıf Düzeyi Bakımından Karşılaştırılması

\begin{tabular}{|c|c|c|c|c|}
\hline Kategoriler & $\begin{array}{l}\text { 1. Sinif } \\
(\mathrm{n}=37) \\
\mathrm{f}(\%)\end{array}$ & $\begin{array}{l}\text { 2. Sinif }(n=35) \\
f(\%)\end{array}$ & $\begin{array}{l}\text { 3. Sinif }(n=24) \\
\text { f }(\%)\end{array}$ & $\begin{array}{l}\text { 4. Sinif }(n=36) \\
\text { f }(\%)\end{array}$ \\
\hline $\begin{array}{l}\text { Yol gösteren ve bilgiye ulaştıran bir } \\
\text { kaynak olarak sosyal medya }\end{array}$ & $\begin{array}{l}10 \\
(\% 27,70)\end{array}$ & $14(\% 40)$ & $11(\% 45,70)$ & $15(\% 41,70)$ \\
\hline $\begin{array}{l}\text { Bağımlılık yaratan bir unsur olarak } \\
\text { sosyal medya }\end{array}$ & $\begin{array}{l}15 \\
(\% 40,70)\end{array}$ & $6(\% 17,10)$ & $4(\% 16,70)$ & $13(\% 36,10)$ \\
\hline $\begin{array}{l}\text { Gerçeği yansitan ve etkileşimi sağlayan } \\
\text { bir araç olarak sosyal medya }\end{array}$ & $\begin{array}{l}6 \\
(\% 16,70)\end{array}$ & $6(\% 17,10)$ & $1(\% 4,10)$ & $2(\% 5,50)$ \\
\hline Zaman kaybı olarak sosyal medya & $\begin{array}{l}5 \\
(\% 13,70)\end{array}$ & $1(\% 2,80)$ & $7(\% 29,10)$ & $3(\% 8,30)$ \\
\hline $\begin{array}{l}\text { Gereksinim olarak sosyal medya } \\
\text { Gizlenme alanı olarak sosyal medya }\end{array}$ & $1(\% 20)$ & $8(\% 22,70)$ & $1(\% 4,10)$ & $\begin{array}{l}2(\% 5,50) \\
1(2,70)\end{array}$ \\
\hline
\end{tabular}

Sosyal Bilgiler öğrencilerinin oluşturdukları metaforlara bağlı olarak geliştirilen 6 kavramsal kategorinin öğrencilerin sınıf düzeyi bakımından dağılımının gösterildiği Tablo 5 te ise, araştırmaya katılan 1. sınıf öğrencileri en fazla $(\% 40,70)$ "bağımlılık yaratan bir unsur olarak sosyal medya" kategorisinde yoğunlaştığı, en az (\%20) ise "gereksinim olarak sosyal medya" kategorisine metafor geliştirdikleri görülmüştür. 2. sinıflar ise en fazla $(\% 40)$ "yol gösteren ve bilgiye ulaştıran bir kaynak olarak sosyal medya", en az $(\% 2,80)$ "zaman kaybi olarak sosyal medya" kategorilerine metafor geliştirirken; araştırmaya katılan 3. sınıfların en fazla $(\% 45,70)$ "yol gösteren ve bilgiye ulaştıran bir kaynak olarak sosyal medya", en az $(\% 4,10)$ "gerçeği yansitan ve etkileşimi sağlayan bir araç olarak sosyal medya" ile "gereksinim olarak sosyal medya" kategorilerine metafor geliştirdikleri belirlenmiştir. Araştırmaya katılan 4. sınıf öğrencilerinin de en fazla $(\% 41,70)$ ile "yol gösteren ve bilgiye ulaştıran bir kaynak olarak sosyal medya" kategorisinde yoğunlaştığı, en az ise (\%2,70) "gizlenme alanı olarak sosyal medya" kategorisinde yer aldıkları çalışma sonunda tespit edilmiştir.

\section{Tartışma, Sonuç ve Öneriler}

İletişim teknolojilerinin hızla gelişmesiyle birlikte hayatımızda giderek önemi artan ve vazgeçilmezler arasına giren sosyal medya, kullanıcıların kendilerini interaktif ortamda ifade ettikleri bir çeşit sanal medyadır. Araştırmaya katılan öğretmen adayları tarafından "sosyal medya" kavramına yönelik toplam 58 metafor geliştirilmiştir. Katılımcılar sosyal medyayı en fazla $(\% 12,70 / f=17)$ "uyuşturucu“ ya benzetirken; en az yoğunlaştıkları metaforlar "öğretmen, lastik, zurna, işçi, organ, yol, obezite, kum saati, maskeli balo, moda akımı, bedevi, cadı kazanı, yarış atı, pazar yeri, oyuncak, kasaba, elma kurdu, kartal, çekirdek, güneş, bebek, baharat, ilistir, 
uzay boşluğu, diktatör, gece gündüz, hayat, hücre, boş sayfa, telgraf teli, uyku, ruhsuz beden, popüler bir şark1, volkan, çay, kitap kapağı" $(\% 0,70 / \mathrm{f}=1)$ olmuştur. Bu metaforlardan hareketle katılımcılar sosyal medya kavramını birden fazla sembolik kavramla ifade ederek farklı düşünüş tarzlarını sergilemişlerdir. Nitekim sosyal medya insanların bir yandan iletişim ve bilgi paylaşımını olumlu yönden etkilerken diğer taraftan toplumdan soyutlanma, psikolojik (depresyon) ve fizyolojik (uyku eksikliği) vb. sorunlar yaratarak insanlara birçok yönden olumsuz etkileri olabilmektedir. Özellikle günümüz üniversite gençliği toplumsal olanakların çoğuna sahip olma bakımından birçok fırsatı elinde bulundurmakta ve bu firsatları da istedikleri yönde kullanabilmektedirler (Akınc1-Vural ve Bat, 2010; Koçoğlu, 2014). Dolayısıyla katılımcıların sosyal medyadan farklı düzeylerde etkilenmeleri ve onu algılama biçimlerinde farklılıklar görülmesi olağandır.

Sosyal medyanın insanlar tarafından nasıl algılandığını belirlemek amacıyla da birçok araştırma yapılmıştır. Yapılan pek çok çalışmada genelde sosyal medyanın bilgiye ulaştıran, yol gösteren ve işbirliğine dayalı öğrenmeyi destekleyen bir uygulama olduğu vurgulanmıştır (Bruce, 1999; Hazar, 2011; Honeycutt ve Herring 2009; Manzo, 2009; McCool, 2011). Sosyal Bilgiler Öğretmenliği öğrencilerinin sosyal medya algılarını ortaya çıkarmak amacıyla yapılan bu çalışmada da katılımcıların \%37,70'i yapılan çalışmalarla aynı doğrultuda sosyal medyayı yol gösterici ve bilgiye ulaştırıcı bir kaynak olarak ifade etmişlerdir. Ancak öğrencilerin büyük bir bölümü sosyal medyayı bilgiye ulaşmada bir araç olarak görürken gereksiz bilgi yığınına sebebiyet verdiklerini de vurgulamışlardır. Gelişen teknoloji ve internetin sunduğu olanaklar sayesinde gündelik hayatın vazgeçilmez bir parçası haline gelen sosyal medya, bilgi kaynaklarına hızlı ulaşma, dünyadaki gelişmelerden anında haberdar olma, yakınımızda olmayan kişilerle hızlı haber alışverişini sağlama gibi birçok kolaylaştırıcı işleve sahipken, yüz yüze ilişkilerin azalmasına, kitap okuma alışkanlığının yok olmasına, çok fazla zamanın harcanmasına sebebiyet vermektedir. Teknolojinin günümüzde kolay ulaşılabilir olması yeni bir bağımlılık türü olarak nitelenebilecek internete ve dolayısıyla sosyal medya ağlarına bağımlılığına yol açmaya başlamıştır. Çalışmaya katılan öğretmen adaylarının özellikle 1. sınıf öğrencilerinin $(\% 40,70)$, sosyal medyayı yoğun bir şekilde kullanmaya devam ederken aslında bu durumunun farkında olarak sosyal medyayı bağımlılık yaratan bir unsur olarak tasvir eden metaforlar geliştirdikleri görülmüştür. Benzer şekilde Hazar (2011) çalışmasında 1. sınıf öğrencilerinin sosyal medya bağımlılıklarını diğer sınıflara oranla daha çok yaşadıklarını ortaya koymuştur. Öğrencilerin özellikle 1. sınıfta üniversite öğrenimi için yaşadıkları şehirden ayrılmaları nedeniyle bulundukları şehirde yeni bir sosyal çevre kuramamaları, yine diğer içsel ve çevresel nedenlerle sosyal yaşamdan kopmaları onların sosyal medyaya daha fazla ihtiyaç duymalarına ve sosyal medyada daha fazla vakit geçirmelerine neden olduğu düşünülebilir. Aynı doğrultuda Kubey, Lavin ve Barrows (2001) da istedikleri gibi sosyal ilişki kuramayan ve engeller yaşayan bireylerin yeni sosyal ilişkiler oluşturmak ve sürdürmek için sıklıkla internete başvurdukları ve interneti yüz-yüze iletişimin yerine koyduklarını belirtmişlerdir. Bu bağlamda internet kullanımının yalnızlığa neden olabileceği görüşünü öne süren Morahan-Martin'e (1999) göre, internet kullanımı öncelikle sosyal ilişkilerde gerçek yaşamın yerini almakta, böylece kullanıcıları yalnızlığa itmektedir. Yine Kandell (1998) yapmış olduğu çalışmada 
üniversite öğrencilerinin diğer öğrencilerden daha fazla internet bağımlısı olduğunu belirtmektedir. Buna gerekçe olarak da üniversite öğrencilerinin evlerinden uzakta yaşamaları ve mevcut eğitim sisteminin de öğrencileri internete dolayısıyla sosyal ağlara yönlendirdiğini göstermişlerdir. 1. sınıf öğrencilerinden sonra, çalışmada sosyal medyayı bağımlılık yaratan bir unsur olarak en fazla 4. sınıf öğrencilerinin tasvir ettikleri tespit edilmiştir. 4. sınıf öğrencileri bir yandan lisans eğitimlerindeki dersleri bitirmeye çalışırlarken diğer taraftan da kaygılı, umutsuz ve yoğun bir biçimde KPSS hazırlıklarına devam etmektedirler. Sezgin ve Duran'in (2011) çalışmasında özellikle KPSS'nin 4. sınıf öğrencilerin çevreyle iletişimlerini, sosyal ilişkilerini ve sanatsal, kültürel ve sportif faaliyetlere katılımlarını olumsuz etkilediği sonucuna ulaşmıştır. Bu bağlamda KPSS'nin 4. sınıf öğrencileri üzerinde psikolojik baskı oluşturması öğrencilerin kendilerini rahatlatma ve sınav psikolojisinden biraz olsun uzaklaşmak için sosyal medyaya yöneldikleri ve zaman içerisinde de sosyal medyada daha fazla zaman geçirmeleri nedeniyle sosyal medyayı bağımlılık olarak gördükleri düşünülebilir.

Araştırmada yine sosyal medyanın gerçeği yansıtan ve etkileşimi sağlayan bir araç olduğuna dair katılımcılar tarafından metaforlar geliştirilmiştir. Bu kategoride katılımcılar (\%11,70'i) sosyal medyanın gerçeği yansıttığına özellikle vurgu yapmışlardır. Ancak bilindiği üzere medyanın hızlı gelişmesiyle birlikte aile, okul, öğretmen, kitap ve diğer bilgi kaynakları artık günümüzde eski rollerini korumakta güçlük çekmektedirler. Bu bağlamda medya kanalıyla elde edilen bilgilerin doğru ve güvenilir olduğunu teyit edip olgusal gerçekleri yansıtıp yansıtmadığına dikkat edilmelidir. Çünkü sayısız internet sitesi, televizyon, gazete ve radyo kuruluşları aracılığıyla bilgi akışı sağlanmakta, bu da bilginin hızla yayılmasına, doğruluğu üzerinde de şüpheler uyandırmasına sebep olmaktadır.

Kert ve Kert (2010) tarafından yapılan çalışmanın sonucunda da bu araştırmanın sonucuyla paralel olarak sosyal medyanın öğrencilerin gereğinden fazla zamanını aldığı saptanmıştır. Öğrencilerin \%12'si bu konuda ortak görüş belirtmektedirler. Bu bulgu araştırma sonucunu destekler niteliktedir. Yine Akınc1Vural ve Bat'ın (2010) çalışmalarında da sosyal medya en fazla "zaman geçirmek" amacıyla kullanılmaktadır $(\% 31,00)$. Youth Insight adlı araştırma şirketi tarafından gerçekleştirilen "sosyal medya araştırması" gençlerin sosyal medya kullanım saatlerinin arttığını ortaya koymaktadır. Araştırma sonuçlarına göre gençlerin 25 saat hafta içi, 25 saat hafta sonu olmak üzere haftada toplam 50 saatlerini sosyal medyada geçirdikleri tespit edilmiştir. Ayrıca üniversite öğrencilerinin \%71'i en çok 20:00 02:00 saatleri arasında sosyal ağlarda aktif oldukları belirlenmiştir (Youth Insight Sosyal Medya Araştırması, 2011).

İnsanların mutlu bir hayat sürdürebilmeleri için temel ve sosyal ihtiyaçlarının giderilmesi gerekmektedir. Araştırma da katılımcılar (\%9,70'i) sosyal medyayı bir gereksinim olarak görmüş ve onu yaşamın ayrılmaz bir parçası haline geldiğini ifade eden metaforlar geliştirmişlerdir. Günümüzde bilginin önemi ve yaşam boyu öğrenmeye duyulan gereksinim her geçen gün artmaktadır. Bu bağlamda özellikle sağlık, eğitim, kültür vb. alanlarda internet kaynakları ve özellikle sosyal medya ilk başvuru kaynağı haline gelmiştir. Bunun yanı sıra kısa zamanda organize olmayı kolaylaştırması, bireyler arasında iletişimi artırması, fikirlerin hızla yayılması ve iletişim maliyetinin düşük olması sosyal medyanın insanlar arasında 
ihtiyaç olarak görülmesini kolaylaştırarak onları sosyal medyada daha fazla zaman geçirmelerine teşvik etmiştir. Bu bağlamda doğru kullanılmadığı takdirde bağımlılığa ideal ortam hazırladığı düşünülebilir. Bu ölçüde etki gücüne sahip sosyal medya içeriklerinin bağımlılık yaptığı bilinmeli ve bu bilinçle hareket edilerek gerektiği kadar takip edilmelidir.

Birey sosyalleşme adı altında kişilerle olan iletişimi sonucu, kendini kişilere olduğundan farklı şekilde yansıtma ihtiyacı duyabilmektedir. Bunda kişinin kendini hedef seçtiği gruba kabul ettirme ve uzağa itilmeme isteği ön plandadır (Cüceloğlu, 2014; Özkan, 2013). Araştırmada da yalnızca 1 katılımcı sosyal medyayı gizlenme alanı olarak gördüğünü ifade etmiş, başkalarının bizi nasıl gördüğünün daha önemli olduğunu vurgulamıştır. Sosyal medya kullanıcıların ismini, cinsiyetini, toplumsal rol ve statüsünü gizleyerek sanal kimliklerle daha önce yüz yüze iletişim kurmadığ1 insanlarla ilişki kurmasına fırsat tanır. Elbette iletişim içinde bulunulan insanların birbirlerini nasıl algıladıkları önemlidir. Ancak sosyal medya aracılığıyla insanların algılarını olumlu ya da olumsuz yönde değiştirebilmek için gerçek dışı kimliklere bürünüp aldatıcı davranışlardan kaçınmak sağlıklı iletişim kurabilmek için önemlidir.

Sosyal medyaya yönelik olumsuz olarak geliştirilen metaforlar sosyolojik açıdan incelenerek öğrencilerin büyük bir bölümünde olumsuz bir izlenim bırakmasının sebepleri araştırılmalıdır. İnsan üzerindeki etkileri bilinmesi, öğretmen adaylarının da bunun farkında olmalarına rağmen dünyada bir akım haline dönüşen sosyal medyadan uzak kalamamaları incelenmeye değer bir konu olarak karşımızda durmaktadır. Bu çalışmanın bir benzerinin aktif olarak görev yapan öğretmenlere de uygulanmasının ve öğretmenlerin sosyal ağları ne sıklıkla ve hangi amaçlar doğrultusunda kullandıklarının belirlenmesinin de karşılaştırma yapmak adına alana katkı sağlayacağı düşünülmektedir.

\section{Kaynakça}

Akçalı İçin, S. (2009). Çocuk ve medya. Ankara: Nobel Yayın Dağıtım.

Akınc1-Vural, Z. B. ve Bat, M. (2010). Yeni bir iletişim ortamı olarak sosyal medya:

Ege üniversitesi iletişim fakültesine yönelik bir araştırma, Journal of Yaşar University, 20(5), 3348-3382.

Arslan, A. (2004). Medyanın birey, toplum ve kültür üzerine etkileri. Uluslararası Insan Bilimleri Dergisi, 1(1), 1-12.

Atıcı, B. (2010). Sosyal bilgi inşasına dayalı sanal öğrenme çevrelerinin öğrenci başarısı ve tutumlarına etkisi. Eğitim ve Bilim, 32(143), 41-54.

Aydeniz, H. (2011). Medyayı tanımak. İstanbul: Eğitim Danışmanlığı ve Araştırmaları Merkezi.

Barış, E. (2011). Yeni medya ve sosyal hareketler.

http:/ / ekitap.alternatifbilisim.org/files/cesur-yeni-medya.pdf adresinden erişilmiştir.

Barış, F. M. ve Tosun, N. (2013). Sosyal ağ ve e-portfolyo entegrasyonu: Facebook örneği. Ĕgitim ve Öğretim Araştırmaları Dergisi, 2(2), 122-129.

Bilgin, N. (2014). Sosyal bilimlerde içerik analizi teknikler ve örnek çalışmalar. Ankara: Siyasal Kitabevi. 
Blank, G. ve Reisdorf, B. C. (2012). The participatory web. Information, Communication, Society, Oxford Internet Institute, 15(4), 537-554.

https:/ / doi.org/10.1080/1369118X.2012.665935

Boyd-Barret, O. ve Braham, P. (2013). Media, knowledge and power. New York:

Routledge. https://doi.org/10.4324/9781315002712

Bruce, H. (1999). Perceptions of the internet: What people think when they search the Internet for information. Internet Research: Electronic Networking Applications and Policy, 9(3), 187-199. https:/ / doi.org/10.1108/10662249910274575

Büyükşener, E. (2009). Türkiye' de sosyal ağların yeri ve sosyal medyaya bakış. XIV. Türkiye'de Internet Konferansı Bildirileri. ttp:/ / www.seokursu.com.tr/turkiyedesosyal-aglarin-yeri.pdf. adresinden erişilmiştir.

Cüceloğlu, D. (2014). Insan insana. Ankara: Remzi Kitabevi.

Dabbagh, N. ve Kitsantas, A. (2012). Personal learning environments, social media, and self-regulated learning: A natural formula for connecting formal and informal learning. The Internet and Higher Education, 15(1), 3-8.

https:/ / doi.org/10.1016/j.iheduc.2011.06.002

Das, R. (2010). The task of interpretation. Converging perspectives in audience research and digital literacies. Estonya: Tartu University Press.

Eroğlu, Y. ve Peker, A. (2011). Aileden ve arkadaştan algılanan sosyal destek ve siber mağduriyet: Yapısal eşitlik modeliyle bir inceleme. Akademik Baklş Dergisi, 27, 115.

Gürbüz. G. (2014). Sosyal medya ve demokrasi ilişkisi: Türkiye'de sosyal medyanın katılımcı demokrasiye etkisi üzerine bir alan araştırması (Yayınlanmamış Yüksek Lisans Tezi). Atatürk Üniversitesi Sosyal Bilimler Enstitüsü, Erzurum.

Güz, N. (1996). Türk basınında gündem oluşturma. Yeni Türkiye Medya Özel Sayısı, 2(12), 982-983.

Hazar, M. (2011). Sosyal medya bağımlılığ1-bir alan çalışması. Gazi Üniversitesi İletişim Fakültesi İletişim Kuram ve Araştırma Dergisi, 32, 151-173.

Honeycutt, C. ve Herring, S. C. (2009). Beyong microblogging: Conversation and collaboration via twitter. Proceedings of the Forty-Second Hawai'i International Conference on System Science: Los Alamitos.

Jakubowicz. K. (2009). A new notion of media? 1st council of europe conference of ministers responsible for media and new communication services.

http://www.coe.int/t/dghl/standardsetting/media/Doc/New_Notion_Medi a_en.pdf. adresinden erişilmiştir.

Kandell, J. (1998). Internet addiction on campus the vulnerability of college students. Cyberpsychology and Behavior, 1, 46-59. https://doi.org/10.1089/cpb.1998.1.11

Kaplan, A. M. ve Haenlein, M. (2010). Users of the world, unite! the challenges and opportunities of social media. Business Horizons, 53(1), 59-68.

https:/ / doi.org/10.1016/j.bushor.2009.09.003.

Kaya, R. (1999). Medya gücü ve demokratik kurumlar. İstanbul: Afa Yayıncılık.

Kert, A. ve Kert, S. B. (2010). The usage potential of social network sites for educational purposes. International Online Journal of Educational Sciences, 2(2), 486-507. 
Kietzmann, J. H., K. Hermkens, I. P. McCarthy ve B. S. Silvestre (2011). Social media? get serious! Understanding the functional building blocks of social media.

Business Horizons, 54(3), 241-251. https:/ / doi.org/10.1016/j.bushor.2011.01.005.

Klieber, P. (2009). Document classification through data mining social media networks. Stetson University. Erişim Tarihi (02.04.2017).

http:/ / digital.archives.stetson.edu/cdm/ref/collection/Research/id/2097 adresinden alınmıştır.

Kocadaş, B. (2005). Kültür ve medya. Bilig, 34, 1-13.

Koçoğlu, E. (2014). Sosyal Bilgiler Öğretmenlerinin Mesleki Yeterliliklerine İlişkin Öğrenci Algılar1. Karadeniz Sosyal Bilimler Dergisi, 5(9), 207-227.

Koçoğlu, E. (2017). Perceptions of teacher candidates about social network usage levels in Turkey. Educational Research and Reviews, 12(4), 230-238. https:/ / doi.org/10.5897/ERR2016.3097

Krippendorff, K. (2004). Content analysis. London: Sage Publications.

Kubey R. W., Lavin M. J. ve Barrows J. R. (2001). Internet use and collegiate academic performance decrements: Early findings. Journal of Communication, 5, 366-382. https:/ / doi.org/10.1111/j.1460-2466.2001.tb02885.x.

Manzo, K. K. (2009). Twitter lessons in 140 characters or less. Education Week. 29(8), 114.

McCool, L. B. (2011). Pedagogical use of twitter in the university classroom (Unpublished Master's Thesis). Iowa State University, Ames, Iowa.

Miles, M. B. ve Huberman, A. M. (1994). Qualitative data analysis. CA: Sage Publications.

Morahan-Martin, J. M. (1999). The relationship between loneliness and internet use and abuse. Cyberpsychol Behavior, 2, 431-439. https://doi.org/10.1089/cpb.1999.2.431.

O'Keeffe, G. S. ve Clarke-Pearson, K. (2011). The impact of social media on children, Adolescents and Families. Pediatrics, 127(4), 800-804. https:/ / doi.org/10.1542/ peds.2011-0054

Özdemir, S. (1998). Medya emperyalizmi ve küreselleşme. İstanbul: Timaş Yayınları.

Özkan, N. P. (2013). Sosyal ăg kullanıcılarının e-sosyalleşme sürecindeki kimlik yapılandırma süreçleri. http:/ / www.cmdconf.net/2013/makale/PDF/88.pdf adresinden erişilmiştir.

Öztürk, M. ve Akgün, Ö. E. (2012). Üniversite öğrencilerinin sosyal paylaşım sitelerini kullanma amaçları ve bu sitelerin eğitimlerinde kullanılması ile ilgili görüşleri. Sakarya University Journal of Education, 2(3), 49-67.

Palabıyıkoğlu, R. (1997). Medya ve şiddet. Kriz Dergisi, 5(2), 123-126. https:/ / doi.org/10.1501/0000876

Patton, M. Q. (2002). Qualitative research ve evaluation methods. CA: Sage Publications.

Roblyer, M. D., McDaniel, M., Webb, M, Herman, J. ve Witty, J. V. (2010). Findings on facebook in higher education: A comparison of college faculty and student uses and perceptions of social networking sites. The Internet and Higher Education, 13(3), 134-140. https:// doi.org/10.1016/j.iheduc.2010.03.002.

Rogge, U. J. (1989). Televizyon video delilleri. (L. Çalışkan, Çev.). İstanbul: Afa Yayincilik.

Selwyn, N. (2012). Social media in higher education. In Gladman, A. (Ed.), The Europa world of learning (pp. 1-9). London, UK: Routledge. 
Sezgin, F. ve Duran, E. (2011). Kamu Personeli Seçme Sınavı'nın (KPSS) öğretmen adaylarının akademik ve sosyal yaşantılarına yansımaları. Türkiye Sosyal Araştırmalar Dergisi, 15(3), 9-22.

Subrahmanyam, K. (2013). Ergenlerde yeni medya kullanımının etkileri/sosyal etkiler ve beliren bilişsel etkiler. I. Türkiye Çocuk ve Medya Kongresi Bildiriler Kitabı 2. İstanbul: Çocuk Vakfı Yayınları.

Şahin, M., Sarı, S. V., Özer, Ö. ve Er, S. H. (2010). Lise öğrencilerinin siber zorba davranışlarda bulunma ve maruz kalma durumlarına ilişkin görüşleri. SDÜ Fen Edebiyat Fakültesi Sosyal Bilimler Dergisi, 21, 257-270.

Şişman-Eren, E. (2014). Sosyal medya kullanım amaçları ölçeğinin geliştirilmesi ve bazı kişisel değişkenlere göre incelenmesi. Hacettepe Üniversitesi Eğitim Fakültesi Dergisi, 29(4), 230-243.

Tektaş, N. (2014). Üniversite öğrencilerinin sosyal ağları kullanımlarına yönelik bir araştırma. Tarih Okulu Dergisi, 7(17), 851-870. http://dx.doi.org/10.14225/Joh474.

Yıldırım, A. ve Şimşek, H. (2008). Sosyal bilimlerde nitel araştırma yöntemleri. Ankara: Seçkin Yayınları.

Youth Insight Sosyal Medya Araştırması. (2011). http:/ / sosyalmedya.co/ youthinsight-arastirma-turkiye/adresinden erişilmiştir.

\section{Summary}

\section{Introduction}

Although social media does not make any educational promises to people, it is a source frequently employed especially to reach information and meet people's various social needs in social life. While everyday another study is conducted in the field regarding the social networks, which are very popular especially among youngsters, development processes, and their negative and positive effects on society, there exist a few studies showing how young people use these networks and their views on the effects of these networks. On the other hand, there exists almost no study which analyzes the thoughts of Social Studies preservice teachers, for whom the society has great expectations about the conscious use of social networks which are used by even primary school students. To this end, this study was designed to understand how Ondokuz Mayis University Social Studies preservice teachers perceive and define the concept of "social media".

\section{Method}

The participants of the study are freshmen, sophomores, junior and seniors studying at Ondokuz Mayis University in Social Studies during the fall semester of 2014-2015 academic year. Qualitative research methods were used in the study where participants were asked to complete statements such as 'Social networks are like ............. because .............', and this raw data constituted the basic source of data for the research. The data was processed for content analysis, one of the commonly used techniques in qualitative data analysis. 


\section{Results and Discussion}

According to results derived from findings, a total of 58 valid metaphors were developed. These metaphors can be grouped in six different conceptual categories in the light of their common features. Of these categories, $78 \%$ are represented by 'social networks as guiding sources of information', 'social networks as elements of addiction', and 'social networks as implements reflecting the truth and ensuring interaction'. Further, despite the similarities in the six conceptual categories reflecting the participants' years of studies, their overall perceptions of social networks are rather negative in general.

In this study which aimed to find out the social media perceptions of Social Studies preservice teachers, $37.7 \%$ of the participants stated that social media was a guiding source which enabled them to reach information, which was in parallel with the studies conducted (Honeycutt ve Herring 2009; Hazar, 2011; Manzo, 2009; McCool, 2011; Bruce, 1999). However, while the majority of students viewed social media as a tool to reach information, they also emphasized that it caused unnecessary mass of information. It was found that especially the first year students $(40.7 \%)$ who participated in the study developed metaphors describing social media as a factor, which created dependency while continuing to use social media extensively and being aware of this situation at the same time. Similarly, Hazar (2011) stated in his study that first year students had more dependency on social media when compared with students in their second, third and fourth years. Kert and Kert's (2010) study also found that students spent much more time than actually needed on social media, which was in parallel with the results of this study. Based on the results of this study, it can be recommended that the metaphors developed negatively against the social media are to be analyzed sociologically and the reasons why it has a negative impression on the majority of students should be explored.

\section{Authors' Biodata / Yazar Bilgileri}

Şule EGÜZ İnönü Üniversitesi Eğitim Fakültesi, Türkçe ve Sosyal Bilgiler Eğitimi Bölümü'nde doktor öğretim üyesi olarak görev yapmaktadır.

Şule Egüz is an doctor at Inonu University, Faculty of Education, Department of Turkish and Social Studies Education.

Alper KESTEN Ondokuz Mayıs Üniversitesi Eğitim Fakültesi, Türkçe ve Sosyal Bilgiler Eğitimi Bölümü'nde doçent doktor olarak görev yapmaktadır.

Alper Kesten is an associate professor at Ondokuz May1s University, Faculty of Education, Department of Turkish and Social Studies Education. 